\title{
Functional Heterogeneity in the Bed Nucleus of the Stria Terminalis
}

\author{
Nur Zeynep Gungor and Denis Paré \\ Center for Molecular and Behavioral Neuroscience, Rutgers State University, Newark, New Jersey 07102
}

Early work stressed the differing involvement of the central amygdala (CeA) and bed nucleus of the stria terminalis (BNST) in the genesis of fear versus anxiety, respectively. In 2009, Walker, Miles, and Davis proposed a model of amygdala-BNST interactions to explain these functional differences. This model became extremely influential and now guides a new wave of studies on the role of BNST in humans. Here, we consider evidence for and against this model, in the process highlighting central principles of BNST organization. This analysis leads us to conclude that BNST's influence is not limited to the generation of anxiety-like responses to diffuse threats, but that it also shapes the impact of discrete threatening stimuli. It is likely that BNST-CeA interactions are involved in modulating responses to such threats. In addition, whereas current views emphasize the contributions of the anterolateral BNST region in anxiety, accumulating data indicate that the anteromedial and anteroventral regions also play a critical role. The presence of multiple functional subregions within the small volume of BNST raises significant technical obstacles for functional imaging studies in humans.

Key words: amygdala; anxiety; BNST; fear

\section{Introduction}

In 2009, Walker et al. (2009a) proposed a parsimonious explanation for earlier observations suggesting that the amygdala and bed nucleus of the stria terminalis (BST) play different roles. This model galvanized interest for the field and still stimulates much research. Here, we review the functional and anatomical organization of BNST and then consider empirical findings for and against this model.

It was first observed that BNST lesions do not affect conditioned fear responses elicited by discrete conditioned sensory cues (CSs) (LeDoux et al., 1988; Hitchcock and Davis, 1991; Gewirtz et al., 1998) (Table 1), unless they were very long ( $\geq 8$ min) (Waddell et al., 2006; Walker et al., 2009a). In contrast, BNST lesions impaired the acquisition and recall of contextual fear responses (Sullivan et al., 2004; Duvarci et al., 2009; Poulos et al., 2010), an effect that might depend on the diffuse nature of contextual cues (Hammack et al., 2015).

Other work indicated that BNST's involvement in the genesis of anxiety-like responses is not limited to learned associations but that it extends to unconditioned threats, such as bright lights (Walker and Davis, 1997), predator odors (Fendt

\footnotetext{
Received March 15, 2016; revised May 3, 2016; accepted May 5, 2016.

This work was supported by National Institute of Mental Health Grant R01 MH-098738 to D.P.

The authors declare no competing financial interests.

Correspondence should be addressed to Dr. Denis Paré, Center for Molecular and Behavioral Neuroscience,

Rutgers, State University of New Jersey, 197 University Avenue, Newark, NJ 07102. E-mail: pare@andromeda.rutgers.edu.

DOI:10.1523/JNEUROSCI.0856-16.2016

Copyright $\odot 2016$ the authors $\quad 0270-6474 / 16 / 368038-12 \$ 15.00 / 0$
}

et al., 2003; Xu et al., 2012), and alarm pheromones (Breitfeld et al., 2015). Consistent with this, exploratory behavior in the elevated plus maze (EPM), which assesses the fear of open spaces rodents naturally display, was also found to be dependent on BNST activity (Waddell et al., 2006; Duvarci et al., 2009; Kim et al., 2013).

Overall, these findings led to the theory that BNST mediates sustained anxiety-like responses to diffuse environmental threats (Walker et al., 2009a), as opposed to the central amygdala (CeA), which generates defensive behaviors in response to imminent threats. This parsimonious explanation is well accepted in the BNST literature and guides not only animal (Daniel and Rainnie, 2016), but also human research (Avery et al., 2016). Indeed, despite their psychological and physiological similarities, anxiety and fear are triggered by distinct stimuli. Fear-eliciting cues signal imminent threats with a high probability of occurrence. On the other hand, anxiety arises in the anticipation of uncertain perils (Grupe and Nitschke, 2013). Although most of the studies implicating BNST in aversive responses used such distal and unpredictable threats, other data suggest that BNST also modulates responses to discrete cues. However, before addressing this question, we will briefly summarize major principles of BNST organization.

\section{Anatomical and physiological substrates of BNST functions} Nuclear systematization. BNST's structure is complex and, compared with the amygdala, still poorly understood. BNST is in fact a collection of nuclei, with much disagreement regarding their number and location (e.g., compare Moga et al., 1989 and Ju and Swanson, 1989). Posteriorly located BNST nuclei are involved in 
Table 1. Glossary

\begin{tabular}{|c|c|}
\hline Term & Definition \\
\hline Unconditioned stimulus (US) & Any stimulus that can trigger a response without prior learning experience \\
\hline Conditioned stimulus (CS) & An initially neutral stimulus that gains the ability to evoke responses after being paired with an unconditioned stimulus \\
\hline Cue fear conditioning & $\begin{array}{l}\text { The process by which a discrete and salient sensory stimulus, such as a neutral tone, is paired with a noxious US, usually a mild foot shock. } \\
\text { As a result, the CS acquires the ability to elicit the responses originally associated with the US }\end{array}$ \\
\hline Contextual fear conditioning & The process by which a context where the animal received a noxious US acquires the ability to elicit fear responses \\
\hline Elevated plus maze & An apparatus that consists of open and enclosed arms, used commonly for probing anxiety in rodents \\
\hline Fear & $\begin{array}{l}\text { Various types of short-lived defensive responses elicited by imminent threats. Whereas fear is accompanied by feelings of fright in } \\
\text { humans, it is unclear whether animals also experienced such states }\end{array}$ \\
\hline Anxiety & $\begin{array}{l}\text { Various types of enduring responses elicited by diffuse and uncertain treats. Whereas anxiety is accompanied by feelings of dread in } \\
\text { humans, it is unclear whether animals also experienced such states }\end{array}$ \\
\hline Anxiogenic & Stimulus or process that promotes anxiety \\
\hline Anxiolytic & Stimulus or process that reduces anxiety \\
\hline Fear-potentiated startle & $\begin{array}{l}\text { A paradigm where fear is assessed by measuring startle responses elicited by loud noise bursts. After CS-footshock pairings, noise bursts } \\
\text { presented during the CS elicit higher startle responses }\end{array}$ \\
\hline Cue-induced reinstatement & $\begin{array}{l}\text { In drug dependence experiments, animals are often trained to lever press for drug self-administration when cued with the presentation } \\
\text { of a light and tone compound stimulus. Following self-administration, animals undergo an extinction period where lever responses } \\
\text { decrease but do not completely disappear. Next, in cue-induced reinforcement, reintroduction of the light-tone CS results in an } \\
\text { increase of lever presses, even though no drug is delivered in this part of the experiment }\end{array}$ \\
\hline
\end{tabular}
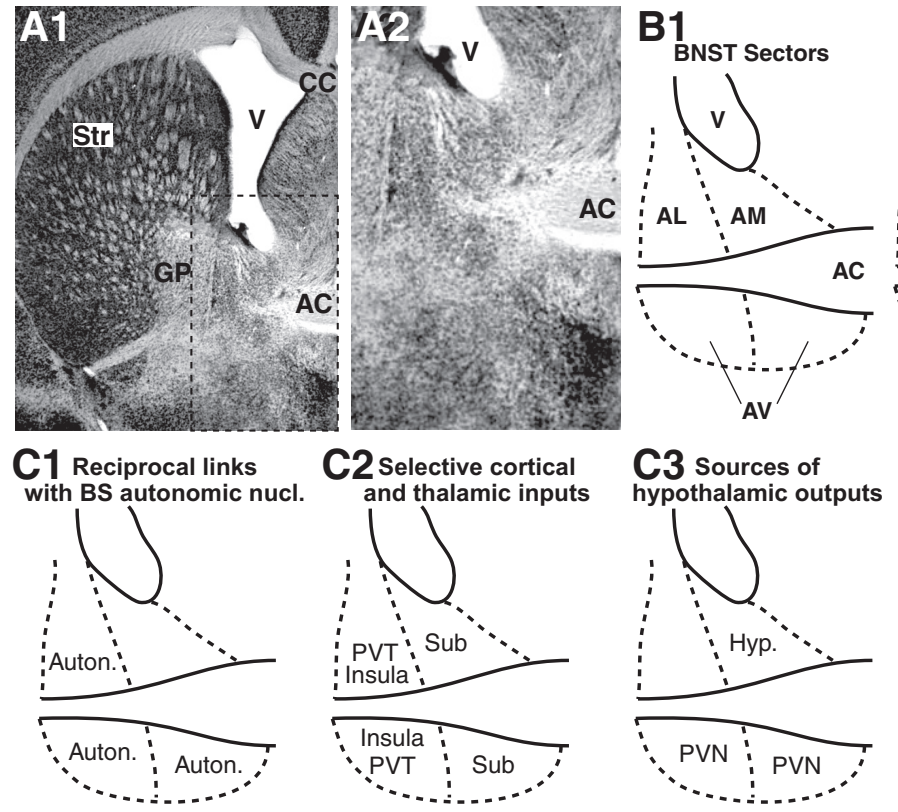

Figure 1. Structure and main connections of BNST. A, Anterior BNST at low (1) and high (2) magnification. Coronal sections processed to reveal NeuN immunoreactivity. $\boldsymbol{B}$, Nomenclature. $\boldsymbol{C}$, Connections. Two major fiber bundles, the intra-BNST segment of the striaterminalis (ST) and the anterior commissure (AC), naturally divide the anterior part of BNST in three sectors: Dorsal to the AC are the AL and AM sectors, located lateral and medial to the ST, respectively. Ventral to the AC is the AV region. In contrast with BNST-AL, BNST-AM receives little or no CeAinputs (see references in main text), (1) it does not project to brainstem autonomic centers (C1) (Norgren, 1976; Ricardo and Koh, 1978; Saper and Loewy, 1980; Schwaber et al., 1982; Sofroniew, 1983; Gray and Magnuson, 1987, 1992; Shin et al., 2008; Panguluri et al., 2009; Bienkowski and Rinaman, 2013); (2) it is innervated by largely distinct cortical areas and thalamic nuclei (C2) (Cullinan et al., 1993; McDonald et al., 1999; Reynolds et al., 2005; Li and Kirouac, 2008; Shin et al., 2008; Bienkowski and Rinaman, 2013); and (3) moreover, its hypothalamic projections are comparably massive (C3) (Conrad and Pfaff, 1976a, b; Saper et al., 1976; Swanson, 1976; Swanson and Cowan, 1979; Kita and Oomura, 1982a; b; Dong and Swanson, 2003, 2004, 2006a, b, c;Dong etal., 2000, 2001b). Although the connectivity of the lateral and medial portions of BNST-AV is similar to that of BNST-AL and AM, respectively, it must be considered separately because of its heavy noradrenergic innervation, among the densest in the brain (C4) (Fallon and Moore, 1978; Forray et al., 2000), as well as its strong projections to the VTA (Dong et al., 2001b; Georges and Aston-Jones, 2002) and PVN of the hypothalamus (Sawchenko and Swanson, 1983; Moga and Saper, 1994). AC, Anterior commissure; Auton, autonomic centers; BS, brainstem; CC, corpus callosum; DA, dopamine; GP, globus pallidus; Hyp, hypothalamus; Jx, juxtacapsular; NA, noradrenaline; Ov, oval; PVT, paraventricular nucleus of thalamus; Sub, subiculum; Str, striatum; V, ventricle.

reproductive behavior (Simerly, 2002) and have received little attention from fear/anxiety researchers. Instead, their experiments initially focused on the anterior BNST region (LeDoux et al., 1988) because it is the main termination zone of CeA axons
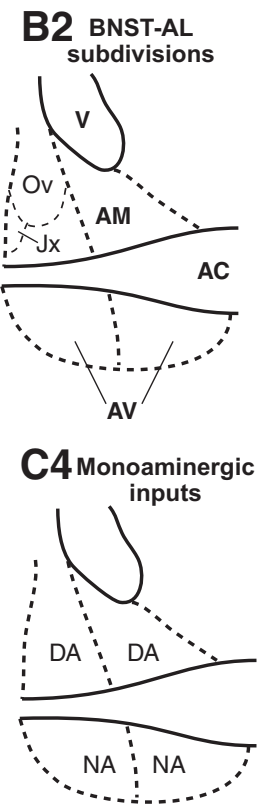

(Krettek and Price, 1978a). However, anterior BNST nuclei are small, often smaller than the dendritic arbor of the neurons they contain (McDonald, 1983; Larriva-Sahd, 2006), precluding their selective targeting in vivo. Moreover, with few exceptions, differences in connectivity between adjacent nuclei are minor. Thus, it seems more productive to use a grouping of anterior BNST nuclei based on regional differences in connectivity. According to this criterion, BNST should be divided in three sectors: anterolateral (AL), anteromedial (AM), and anteroventral (AV). Figures 1 and $2 A$ summarize how different BNST regions receive distinct inputs and contribute contrasting projections.

BNST receives few exteroceptive sensory afferents via the thalamus and cortex. Thus, the massive glutamatergic projections it gets from the basolateral complex of the amygdala (BLA; Fig. 2B) probably play a critical role in determining how organisms respond to environmental contingencies. The three BLA nuclei contribute differentially to this pathway, with the lateral amygdala having no projections, and the basal nuclei contributing prominently (Krettek and Price, 1978a; Weller and Smith, 1982; Dong et al., 2001a). Although both basal nuclei project to BNST's three anterior sectors, their projections are complementary (Fig. 2B). The basomedial (BM) nucleus preferentially targets BNST-AM, whereas the basolateral nucleus (BL) preferentially projects to BNST-AL (Krettek and Price, 1978a; Dong et al., 2001a). Of note, the oval portion of BNST-AL is reportedly devoid of BLA inputs (Dong et al., 2001a).

Physiological cell types and the transmitters they use. So far, five physiological classes of BNST neurons have been described (Hammack et al., 2007; Francesconi et al., 2009; Szucs et al., 2010; 
A

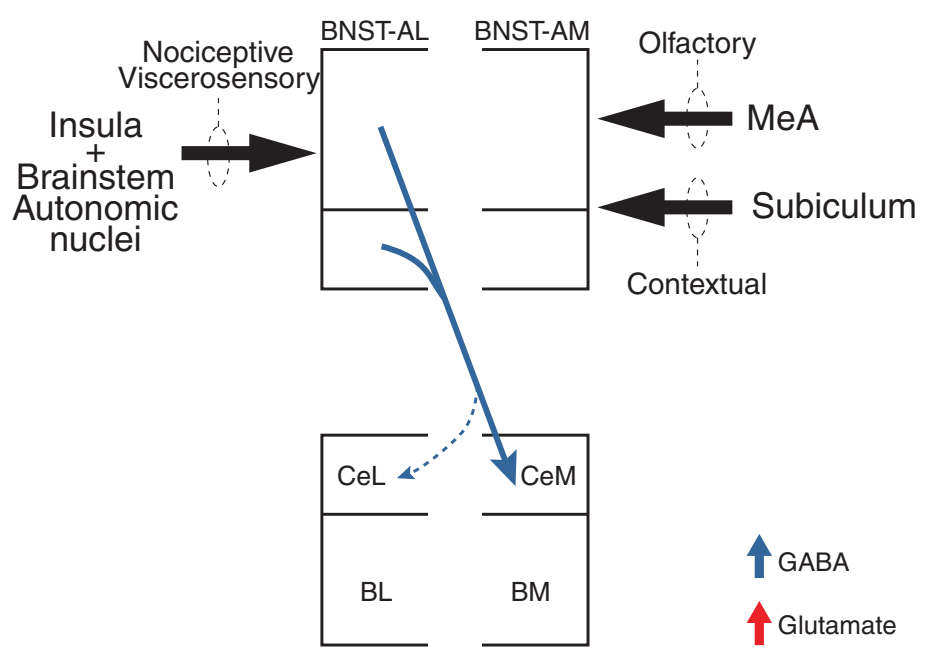

B

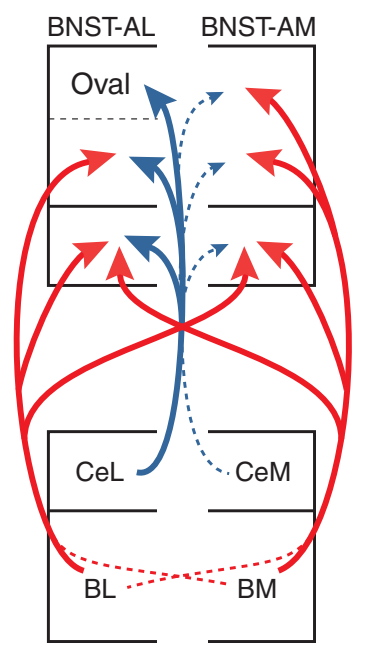

Figure 2. Reciprocal connections between the amygdala and the anterior part of BNST. $A$, BNST projections to the amygdala. Black arrows indicate dominant sensory inputs. MeA, Medial nucleus of the amygdala. $\boldsymbol{B}$, Amygdala projections to BNST.

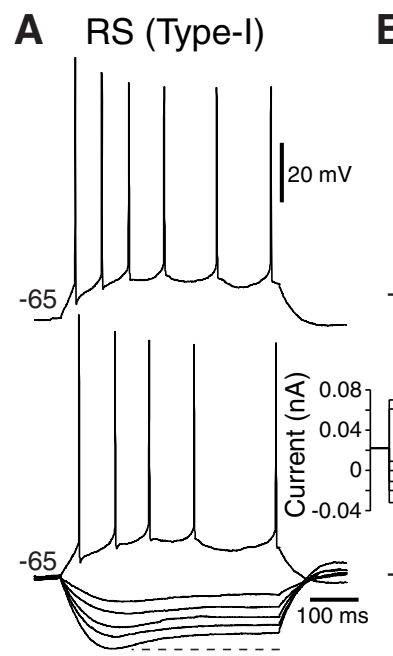

B LTB (Type-II)

E Spontaneously Active

$\mathbf{F}$

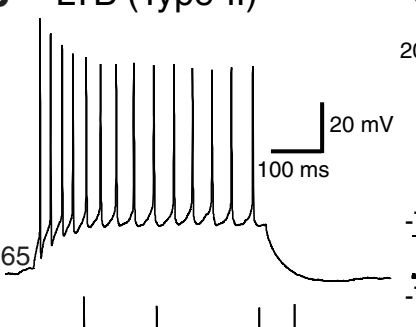

C $\quad$ IIR (Type-III)
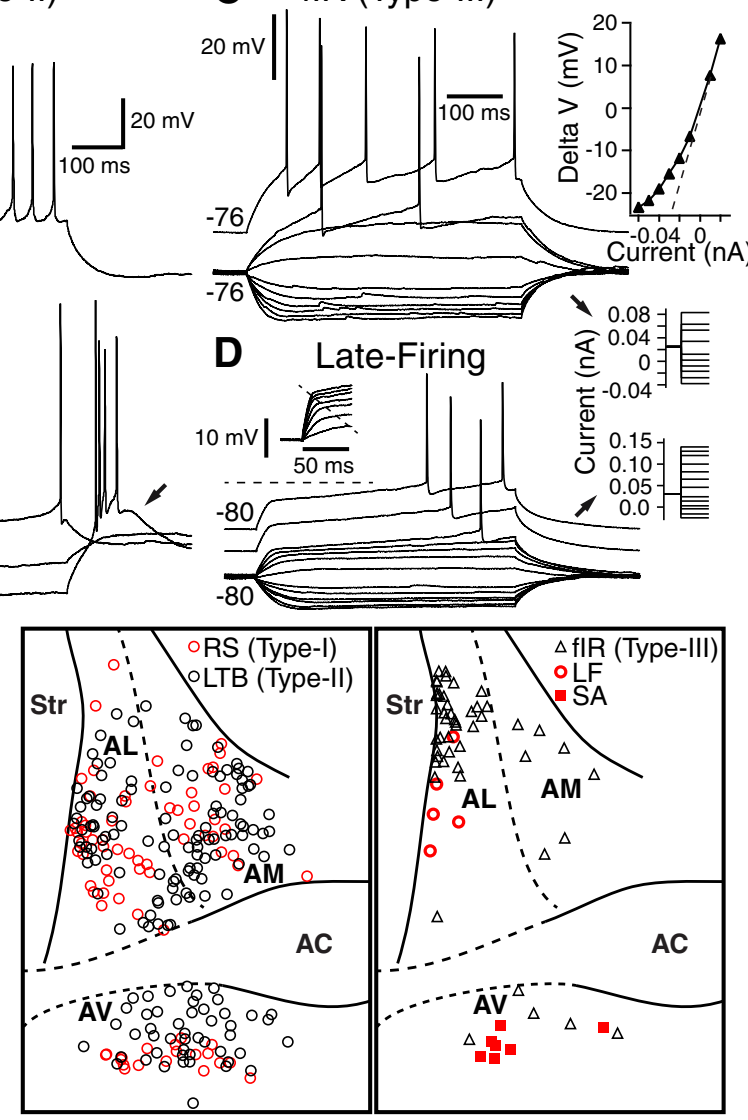

Figure 3. Physiological properties of BNST neurons. Five types have been described ( $\boldsymbol{A}-\boldsymbol{E}$ ). In decreasing order of incidence, they are low-threshold bursting (LTB; Type ll; $\boldsymbol{B})$, regular spiking (RS, Type I; $\mathbf{A}$ ), with a fast inward rectifying $\mathrm{K}^{+}$conductance (fIR; Type III; $\boldsymbol{C}$, late-firing $(\boldsymbol{D})$, and spontaneously active $(\boldsymbol{E})$ neurons. The relative incidence of Type I and II cells is similar in the three BNST regions ( $\boldsymbol{F}$, left), but the other three cell types are mostly found in one of the three regions $(\boldsymbol{F}$, right). Type III cells are concentrated in the oval nucleus, spontaneously active cells in BNST-AV, and late-firing cells in BNST-AL. C, Inset, Amplitude of voltage response to current pulses ( $y$-axis) as a function of current ( $x$-axis). $\boldsymbol{D}$, Inset, Expanded view of initial voltage response to current injection. Modified from Rodriguez-Sierra et al. (2013).

Rodriguez-Sierra et al., 2013) (Fig. 3). Importantly, in BNST-AL, the most common three cell types (Fig. $3 A-C$ ) were accurately clustered by their mRNA expression for different ion channel subunits (Hazra et al., 2011). Most BNST-A neurons, including projection cells, are GABAergic neurons (Cullinan et al., 1993; Sun and Cassell, 1993; Polston et al., 2004; Poulin et al., 2009) that can express a variety of peptides in multiple combinations (Gray and Magnuson, 1987; Ju et al., 1989; Moga et al., 1989). This is the 
case of the corticotropin releasing factor (CRF) cells located in the oval nucleus (Sakanaka et al., 1987; Phelix and Paull, 1990), which also express a fast inwardly rectifying $\mathrm{K}^{+}$conductance (known as Type III cells; Fig. 3C) (Dabrowska et al., 2013a; but see Silberman et al., 2013). It should be noted that the number of CRF-positive BNST neurons is higher in rats than in mice (Wang et al., 2011). In addition to the prevalent GABAergic neurons, BNST-AM and AV also contain a low proportion of glutamatergic cells (Poulin et al., 2009), some of which are projection neurons (Kudo et al., 2012).

Role of the oval nucleus and CRF. Much evidence suggests that CRF exerts anxiogenic effects through its actions in BNST. For instance, intra-BNST (Sahuque et al., 2006) or intracerebroventricular injections of CRF (Lee and Davis, 1997) cause anxiogenic effects, and the latter are blocked by intra-BNST infusions of antagonists for CRF Type 1 receptors (CRF-R1) (Lee and Davis, 1997). Less definitive but also suggestive, oral administration of a CRF-R1 antagonist blocks light-enhanced startle but not conditioned fear to discrete cues (Walker et al., 2009b). Moreover, stressors, such as footshocks, cause an increase in the expression of CRF mRNA in BNST-AL and AV, indicating that CRF cells are activated during stress (for review, see Daniel and Rainnie, 2016). Consistent with this, chemogenetic inhibition of CRF cells (Pleil et al., 2015) or optogenetically inhibiting BNST-AL cells expressing D1-receptors (Kim et al., 2013), thought to be selectively expressed by CRF cells (Daniel and Rainnie, 2016), decrease anxiety in the EPM and open field.

Despite the strong link between CRF and anxiety in BNST, there is still uncertainty regarding the underlying mechanisms. First, given the lack of BLA inputs to the oval nucleus, which structures "inform" CRF cells of environmental contingencies? The oval nucleus is devoid of inputs from the subiculum (Cullinan et al., 1993; McDonald et al., 1999) and medial amygdala (Dong et al., 2001a), sites thought to convey contextual or olfactory information required for responses to threatening contexts and predator odors, respectively. However, it receives viscerosensory afferents from the insula (McDonald et al., 1999; Reynolds et al., 2005) and brainstem autonomic nuclei (Saper and Loewy, 1980; Schwaber et al., 1982) as well as mixed dopaminergicglutamatergic inputs from the periaqueductal gray (Li et al., 2016). Whether these structures provide the critical anxiogenic signals remains to be tested.

Second, in contrast with CRF cells of the paraventricular hypothalamic nucleus (PVN), those found in BNST-AL do not control the release of stress hormones via projections to the pituitary. Thus, their anxiogenic influence likely depends on a modulation of synaptic transmission within BNST itself or at their projection sites. Indeed, CRF cells of the oval nucleus project to various brainstem autonomic nuclei thought to mediate defensive behaviors (Gray and Magnuson, 1987, 1992). Third, these neurons are not the only CRF-expressing elements in BNST. Indeed, BNST-AL receives strong CRF inputs from the lateral sector of CeA (CeL) (Sakanaka et al., 1986). Fourth, while the somatic expression of CRF-R1 mRNA is low to moderate in BNST (Potter et al., 1994; van Pett et al., 2000; Dabrowska et al., 2013a), BNST-AL is heavily innervated by axons expressing this receptor (Justice et al., 2008; Jaferi and Pickel, 2009; Jaferi et al., 2009).

Consistent with this, multiple CRF effects, so far all CRF-R1dependent, have been described. In BNST-AL, CRF presynaptically potentiates glutamatergic transmission (Kash et al., 2008;
Nobis et al., 2011; Silberman et al., 2013). Postsynaptically, CRF was reported to depolarize low-threshold bursting (Type II) cells (Ide et al., 2013), an effect that might explain why CRF increases spike-dependent inhibitory inputs to Type III neurons in the oval nucleus (Nagano et al., 2015). Last, in BNST-AV, CRF postsynaptically increases GABA-A IPSC amplitudes but does not alter EPSCs (Kash and Winder, 2006). Given these multiple and in some cases opposite effects, it remains unclear how CRF contributes to anxiety through its actions in BNST.

$B N S T-A L$. Interestingly, other lines of evidence support the possibility that BNST-AL exerts anxiolytic influences. For instance, BNST-AL stimulation reduces corticosterone levels (Dunn, 1987), whereas BNST-AL lesions increase gastric erosions after stress exposure (Henke, 1984). Moreover, intra-BNST infusions of calcitonin gene-related peptide, a peptide that inhibits non-Type III neurons in BNST-AL (Gungor and Paré, 2014), actually increases acoustic startle and fos expression in targets of BNST-AL (Sink et al., 2011).

In addition, in a variety of stress paradigms, the efficacy of glutamatergic inputs to BNST-AL is reduced. For example, chronic restraint stress causes a depression of glutamatergic inputs to BNST-AL neurons via $\alpha-1$ adrenoreceptors (McElligott et al., 2010). Similarly, chronic cortisol administration and social isolation interfere with the induction of long-term potentiation (Conrad et al., 2011), and withdrawal from various drugs of abuse reduces the intrinsic excitability of BNST-AL neurons (Francesconi et al., 2009). The only exception to this trend was obtained in Type III neurons, in which chronic restraint stress causes a potentiation of glutamatergic inputs (Dabrowska et al., 2013b).

The opposite results obtained in Type III (CRF-expressing) cells suggest that anxiety involves the differential recruitment of different types of BNST-AL neurons. Supporting the notion that functionally distinct cell subpopulations exist in BNST-AL, it was reported that different subsets of BNST-AL cells show lower ( $\sim 25 \%)$ or higher $(\sim 10 \%)$ firing rates during high than low fear states (Fig. $4 B, D$ ) (Haufler et al., 2013). Interestingly, BNST-AM cells show the opposite trend (Fig. $4 A, D$ ). Below, we propose a mechanism for how BNST-AM activity might promote high fear states.

BNST-AM. An analysis of BNST-A's connections (Figs. 1, 2) indicates that BNST-AM is well positioned to mediate BNST's anxiogenic influence. Indeed, BNST-AM is the main recipient of the amygdalar (particularly BM), subicular, and olfactory (medial amygdala) signals that are needed for anxiety-like responses to threatening contexts and odors (Cullinan et al., 1993; McDonald et al., 1999; Dong et al., 2001a). On the output side, BNST-AM projects massively to the hypothalamus. Particularly intriguing in this respect are the complementary projections of $\mathrm{BM}$ and BNST-AM to the ventromedial hypothalamic nucleus $(\mathrm{VMH})$, a node implicated in the genesis of defensive and aggressive behaviors (Gross and Canteras, 2012; Silva et al., 2013; Lee et al., 2014; Wang et al., 2015). Indeed, whereas BM sends glutamatergic projections to the core of VMH (VMH-C) (Petrovich et al., 1996), where the nucleus' glutamatergic output neurons are located, BNST-AM projects to its shell (VMH-S) (Dong and Swanson, 2006a), which contains GABAergic neurons that inhibit core neurons (Fu and van den Pol, 2008). This arrangement suggests that $\mathrm{BM}$ might increase its impact on $\mathrm{VMH}-\mathrm{C}$ by recruiting GABAergic BNST-AM cells, which would then inhibit VMH-S cells, disinhibiting VMH-C neurons. Thus, the synergistic actions of BM and BNST-AM on the VMH are expected to enhance defensive and aggressive behaviors. 


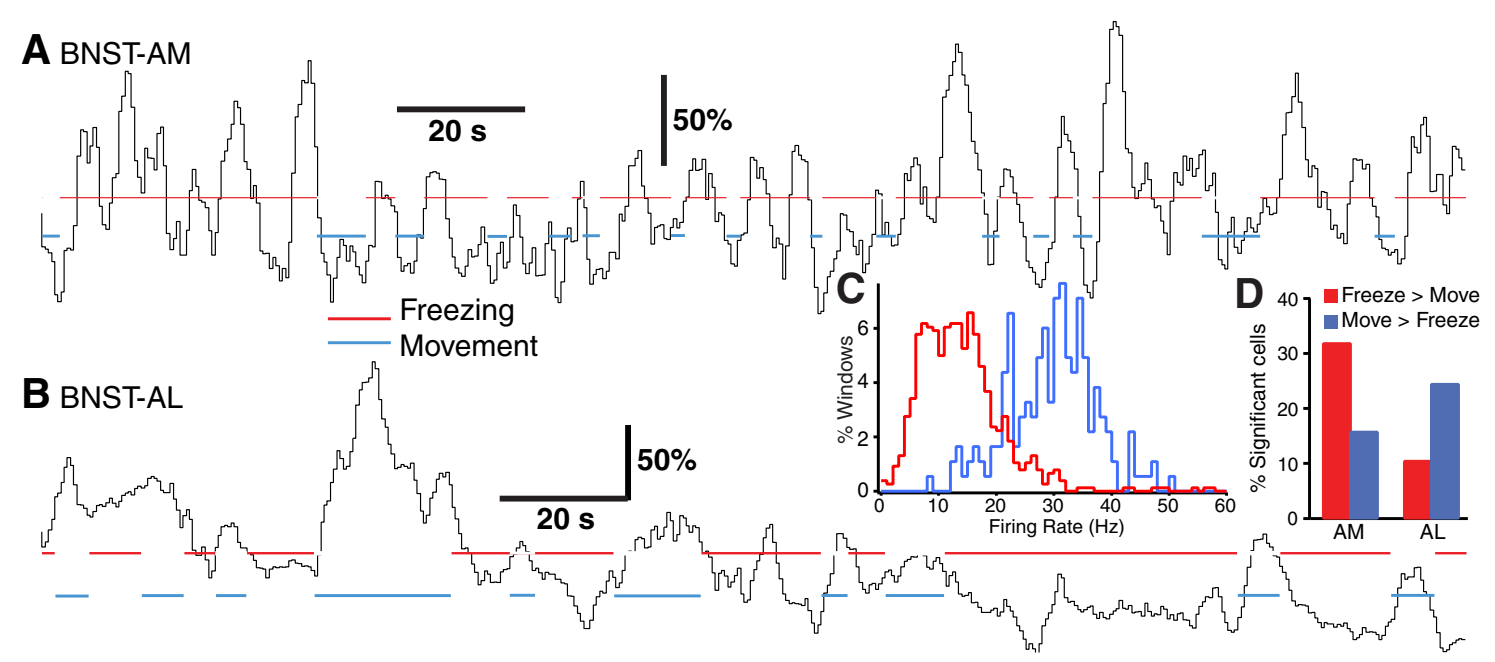

Figure 4. Inverse fluctuations in the firing rate of BNST-AM and BNST-AL neurons in relation to contextual freezing. Rats were subjected to a classical auditory fear conditioning protocol. The next day, while recording BNST neurons, rats were exposed to the conditioning context in the absence of CS. Rats froze $40 \%-50 \%$ of the time during exposure to the aversive context. $A, B$, Black traces represent average firing rates of 5 BNST-AM $(\boldsymbol{A})$ and 3 BNST-AL $(\boldsymbol{B})$ cells during epochs of contextual freezing (red lines) or movement (blue lines). $\boldsymbol{C}$, For all available cells, multiple epochs of freezing (red) or movement (blue) were segmented and distribution of firing rates compared. D, Percentage cells with significantly different firing rates during freezing versus movement in BNST-AM versus AL. Red and blue bars represent cells with higher versus lower firing rates during freezing than movement. Modified from Haufler et al. (2013).

Opposite to this conclusion, however, two recent Nature studies from the same laboratory reported that BLA inputs to BNST-AM (Kim et al., 2013) and BM (Adhikari et al., 2015) exert anxiolytic influences, the latter being "necessary and sufficient" for anxiolysis. This conclusion is puzzling given that their common target, VMH, mediates aversive behaviors, such as avoidance, freezing (Wang et al., 2015) and attack (Lee et al., 2014). Not to mention that both $\mathrm{BL}$ and $\mathrm{BM}$ also send glutamatergic projections to the medial sector of the central amygdala (CeM) (Krettek and Price, 1978b), thought to be the amygdala's main output station for conditioned fear. A possible explanation for these contradictions is that these two Nature reports depended heavily on behavioral observations in the EPM and open field, where predatory or active avoidance behaviors might have been mistakenly interpreted as decreased levels of anxiety.

$B N S T-A V$. BNST-AV is also well positioned to contribute to anxiety-like responses. Indeed, BNST projections to PVN mostly originate from BNST-AV (Sawchenko and Swanson, 1983; Moga and Saper, 1994) and they regulate the HPA axis (Herman et al., 2005). Although some glutamatergic (Csáki et al., 2000) and CRF-expressing (Moga and Saper, 1994) cells project to PVN, most are GABAergic (Radley et al., 2009; Radley and Sawchenko, 2011). These inhibitory neurons receive excitatory inputs from the mPFC and subiculum (Radley et al., 2009; Radley and Sawchenko, 2011) but few from CeA (Prewitt and Herman, 1998). In keeping with this, mPFC (Radley et al., 2009) and hippocampal lesions (Radley and Sawchenko, 2011) decrease the number of fos-positive GABAergic cells in BNST-AV while increasing fos expression in PVN. Although these findings indicate that GABAergic BNST-AV neurons inhibit PVN, other results indicate that the overall influence of BNST-AV over PVN is excitatory. Indeed, global BNST-AV lesions interfere with the recruitment of PVN by various stressors (Crane et al., 2003; Spencer et al., 2005; Choi et al., 2007), whereas selective ablation of GABAergic cells in BNST-AV increases adrenocorticotropic hormone and corticosterone levels after restraint stress (Radley et al., 2009). Overall, these findings suggest that GABAergic cells of BNST-AV inhibit PVN, whereas its glutamatergic cells do the opposite. Surprisingly, although they account for a minority of
BNST-AV cells, the influence of glutamatergic neurons appears to dominate. As a result, BNST-AV as a whole exerts an excitatory influence on PVN.

Interestingly, a similar situation may prevail in BNST-AV's projections to the ventral tegmental area (VTA). Indeed, VTAprojecting glutamatergic cells of BNST-AV increase their firing rate during both aversive unconditioned and conditioned stimuli. In contrast, GABAergic cells are inhibited by both. Optogenetically activating glutamatergic cells produces place aversion and anxiogenic effects, whereas activation of the GABAergic cells produces place preference and anxiolytic effects (Jennings et al., 2013).

Intrinsic BNST connectivity. The data reviewed above emphasizes that BNST is comprised of several functionally important sectors. This situation raises the possibility that anxiety involves inter-regional coordination of activity. Consistent with this idea, tracing (Dong and Swanson, 2003, 2004, 2006a, b, c) and glutamate uncaging (Turesson et al., 2013) studies have revealed that BNST neurons form connections with other cells located in the same or different BNST sectors (Fig. 5). While inhibitory intraregional connections prevail overall, in BNST-AV and the ventral part of BNST-AM, the incidence of glutamatergic and GABAergic connections is similar (Turesson et al., 2013). Although this is surprising given that glutamatergic cells account for minority of the cells (Poulin et al., 2009), this finding is consistent with evidence that glutamatergic BNST-AV cells exert an outsized influence over PVN and VTA neurons (Choi et al., 2007; Radley et al., 2009; Radley and Sawchenko, 2011; Jennings et al., 2013). Importantly, inter-regional connections can be asymmetric or reciprocal, purely inhibitory, or dependent on a mixture of glutamatergic and GABAergic connections (Turesson et al., 2013). For instance, BNST-AL to AM and AV projections are purely GABAergic and markedly stronger than return connections (Fig. 5). Although it is currently unknown whether CRF cells in the oval nucleus contribute to these connections, suppression of firing in GABAergic BNST-AL neurons during high fear states (Haufler et al., 2013) might cause a disinhibition of BNST-AM neurons, contributing to their higher activity levels during contextual freezing (Haufler et al., 


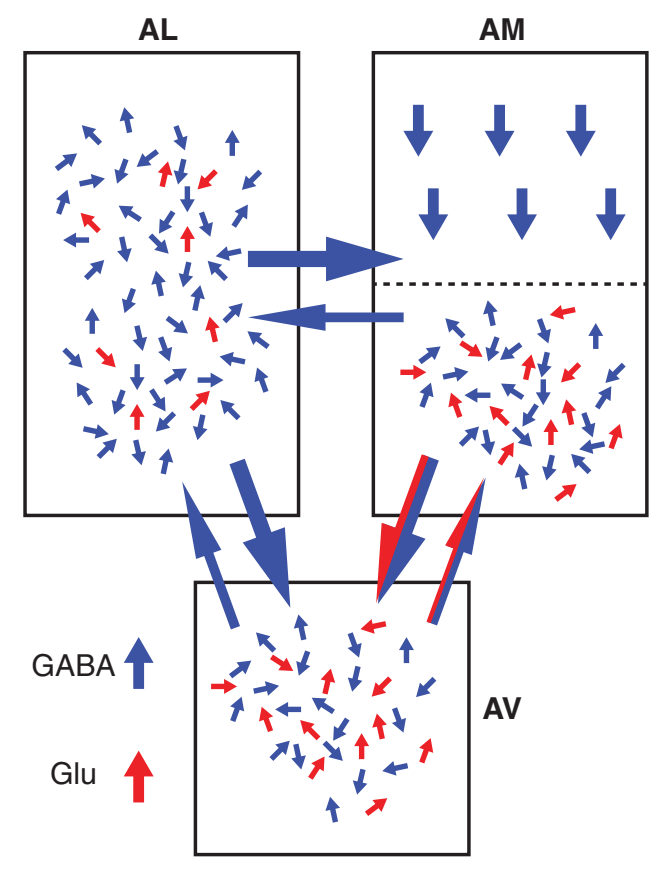

Figure 5. Intrinsic BNST connections. Pattern of intrinsic connections in the anterior BNST, as revealed with glutamate uncaging. Neurons were recorded with the whole-cell method in slices in vitro. Glutamate was uncaged by applying brief flashes of ultra-violet light to a circumscribed region ( $250 \mu \mathrm{m}$ in diameter) of BNST. The light stimulus was moved to systematically scan the slice in search of BNST sites containing neurons projecting to the recorded cell. For intraregional connections, the number of blue (GABAergic) and red (glutamatergic) arrows approximates the relative frequency of inhibitory and excitatory connections, respectively. For inter-regional connections, the thickness of the arrows was adjusted to represent the relative incidence of connections. Data from Turesson et al. (2013).

2013). On the other hand, BNST-AL's influence on BNST-AV will depend on the transmitter content (GABA vs glutamate) of the targeted BNST-AV neurons, which is unknown at this time. Similarly, the significance of the mixed glutamatergic and GABAergic connections between BNST-AM and AV (Turesson et al., 2013) (Fig. 5) is currently unclear.

\section{Amygdala-BNST interactions}

According to the model proposed by Walker et al. (2009a), BL would send threat signals to CeA and BNST. In turn, neurons in CeM would respond immediately, activating downstream fear effectors. By contrast, BNST activation would not only depend on BL activity, but also on CRF inputs from CeL. As a result, BNST's activation would be delayed relative to that of CeM, leading to more slowly developing and longer-lasting anxiety-like states in response to sustained but diffuse threats. This model also proposes that BNST, once active, inhibits CeM, preventing its recruitment during the generation of anxiety-like states. Below, we review empirical findings for and against this model.

CeA involvement in generating responses to long threat-signaling cues. According to Walker and Davis (1997), CeA would not be involved in modulating anxiety-like responses to diffuse and uncertain threats because BNST, once activated, suppresses CeA neurons. Although this prediction found experimental support for unconditioned threats, such as bright lights (Walker and Davis, 1997) or predator odors (Fendt et al., 2003; Li et al., 2004; Rosen, 2004), it did not for the fear of open spaces. Indeed, CeA lesions reduce anxiety-like behavior in the EPM (Möller et al., 1997; Moreira et al., 2007). Similarly, contradictory results were reported for the impact of CeA lesions on conditioned negative associations to long cues or contexts. Although CeA lesions do not block fear-potentiated startle to long cues (Walker et al., 2009a), many found that they reduce freezing to an aversive context (Goosens and Maren, 2001, 2003; Sullivan et al., 2004). However, some failed to find an effect of CeA lesions (Fanselow and Kim, 1994) or concluded that CeA is not involved in the expression but in the consolidation of contextual fear memories (Pitts et al., 2009).

Relative timing of BNST versus CeM activation. Central in the Walker et al. (2009a) model is the notion that BNST activation is delayed relative to that of CeM. However, accumulating data show that the firing rates of BNST neurons are rapidly altered by short and long cues, appetitive or aversive (Haufler et al., 2013; Jennings et al., 2013) (Fig. 6A,B). Moreover, Hammack et al. (2015) showed that, during exposure to a threatening context, the difference in freezing between sham and BNST-lesioned animals is constant for the duration of the context exposure when the model predicts increasing differences with time. Together, these results demonstrate that BNST responses to threatening stimuli or environments are nearly immediate and not necessarily more important the longer the animal is exposed.

BNST involvement in the processing of short-lasting cues. Despite earlier studies showing that BNST does not regulate fear responses to discrete threatening stimuli, accumulating evidence indicates otherwise. During the recall of classically conditioned fear responses, $\sim 25 \%$ of neurons in BNST-AL and AM displayed short-latency alterations in firing rates in response to discrete CSs (Haufler et al., 2013). Consistent with this, muscimol injections in BNST were found to enhance fear-potentiated startle (Meloni et al., 2006), suggesting that BNST exerts tonic inhibitory effects in CeA or their common targets. Support for this notion was obtained by examining the effects of BNST lesions on the CS specificity of conditioned fear responses (Duvarci et al., 2009). In this study (Fig. 6C), rats were subjected to a differential auditory fear conditioning paradigm where a $30 \mathrm{~s}$ auditory $\mathrm{CS}\left(\mathrm{CS}^{+}\right)$was paired to footshocks, whereas another $\left(\mathrm{CS}^{-}\right)$was not. Although BNST-lesioned and sham rats acquired similarly high levels of conditioned fear to the $\mathrm{CS}^{+}$, rats with BNST lesions froze less than sham rats to the $\mathrm{CS}^{-}$, again indicating that BNST activity does affect the processing of short cues.

Additional evidence of short cue processing by BNST comes from the addiction literature. Indeed, a large body of work indicates that BNST plays a critical role in various aspects of addiction, including the dysphoria that follows the pleasurable effects of drug consumption (Wenzel et al., 2011, 2014), in the stress associated with drug withdrawal, and in the reinstatement of drug-seeking (Erb and Stewart, 1999; Aston-Jones and Harris, 2004; Koob, 2009, 2010). In such experiments, animals are trained to lever-press for drug self-administration when presented with a short cue. After an extinction period where lever responses have no effect, reintroduction of cues results in reinstatement of drug seeking behavior. Critically, BNST inactivation interferes with this cueinduced reinstatement (Buffalari and See, 2010).

To summarize this section, although the Walker et al. (2009a) model offers an attractive and parsimonious explanation for the functional dissociation between the amygdala and BNST, some of its key postulations are not supported by available experimental findings. Interestingly, the companion perspective paper (Shackman and Fox, 2016) reached the same conclusion based on an entirely different set of data: functional imaging studies in humans. Thus, although it appears definite that BNST is not required for the genesis of defensive behaviors triggered by discrete threatening cues, equally incontrovertible evidence indi- 

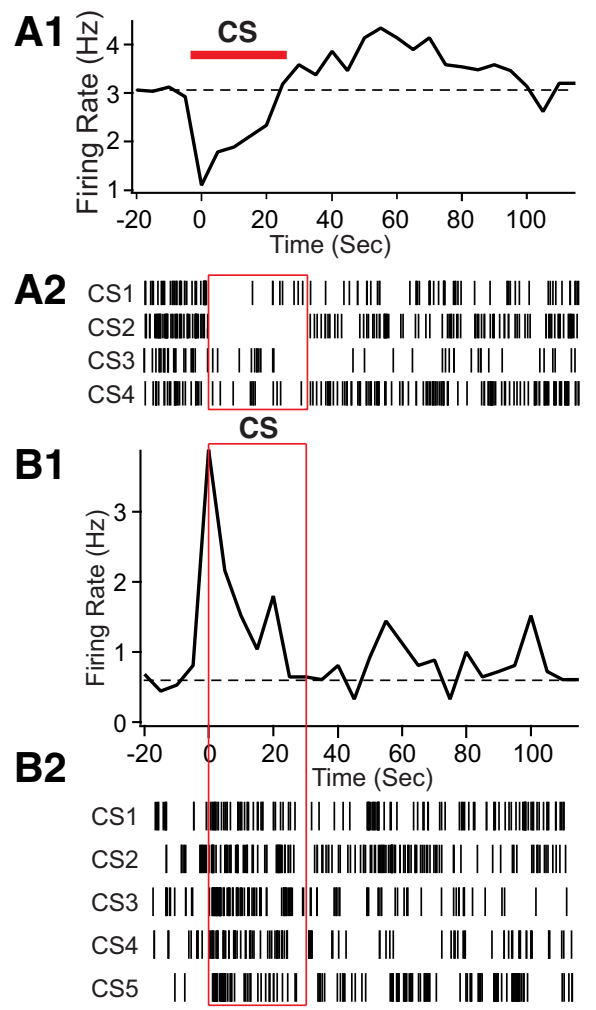

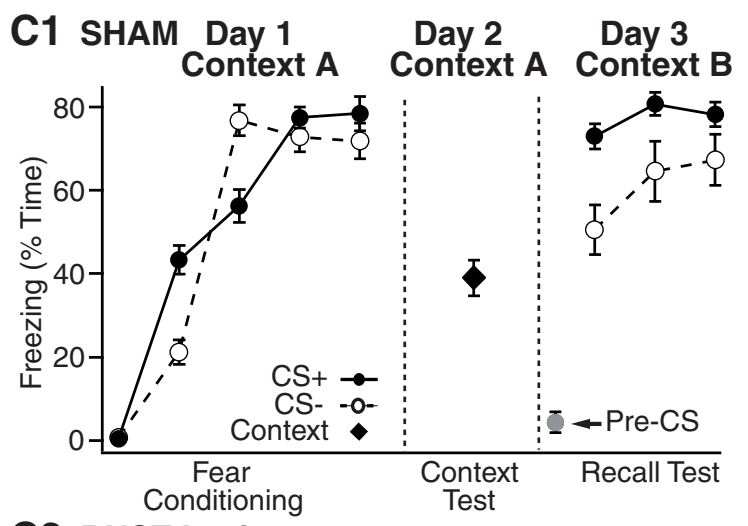

C2 BNST Lesion

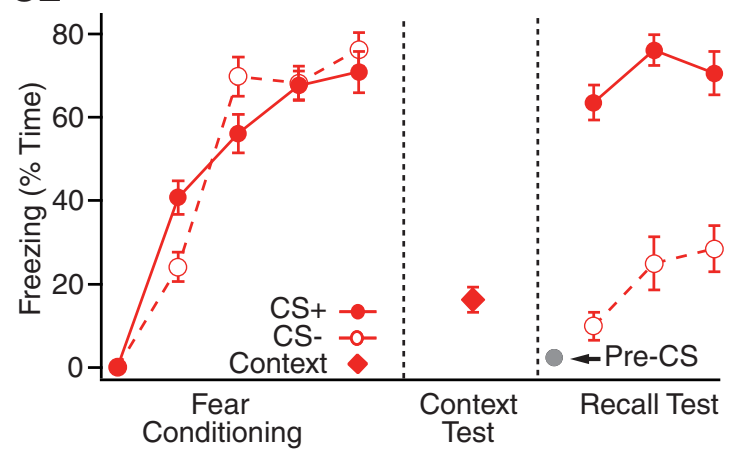

Figure 6. BNST activity alters the processing of discrete threatening stimuli. $A, B$, Two examples of anterior BNST neurons with short-latency responses to discrete threatening cues. These cells were recorded extracellularly in rats that had been subjected to a classical auditory fear conditioning protocol (CS, conditioned stimulus, pure tone). We show (S-evoked activity during the recall test, conducted $1 \mathrm{~d}$ after conditioning. A1, B1, Peri-CS histograms of neuronal discharges. A2, B2, Rasters where each tick represents an action potential. Cells with inhibitory responses prevailed in BNST-AL, whereas cells with excitatory responses were concentrated in BNST-AM. C, Excitotoxic BNST lesions enhance the stimulus specificity of conditioned fear responses. The two graphs compare percentage time freezing to the $\mathrm{CS}^{+}$(filled symbols and solid lines), $\mathrm{CS}^{-}$(empty symbols and dashed lines), or conditioning context exposure in sham (C1, black) or BNST-lesioned (C2, red) rats. There is markedly reduced freezing to the $C S^{-}$with no change in behavior to the $C S^{+}$in BNST-lesioned rats. C, Modified from Duvarci et al. (2009).

cates that it can modulate the processing of such cues. Because BNST projections to the amygdala constitute a likely neuronal substrate for this modulation, the next section describes these connections.

Connections between BNST and CeA. Whereas BNST-AM contributes negligible projections to CeA (Bienkowski and Rinaman, 2013), BNST-AL and BNST-AV project strongly to CeM, and lightly to CeL (Sun and Cassell, 1993; Dong et al., 2001b). BNST to CeA projections prevalently arise from GABAergic neurons, although a few glutamatergic neurons also contribute (Gungor et al., 2015). In the opposite direction, CeA projections to BNST mostly originate in CeL and mainly target BNST-AL, sparring the juxtacapsular region (Dong et al., 2001a). CeM contributes less to BNST's innervation (Sun and Cassell, 1993; Bienkowski and Rinaman, 2013) and BNST-AM receives far weaker inputs from CeA than BNST-AL (Krettek and Price, 1978a; Weller and Smith, 1982; Sun et al., 1991).

Given the asymmetry between BNST to CeA versus CeA to BNST connections (Fig. 2, blue), it is difficult to determine the net impact of their interactions. However, it was reported that CeA axons elicit IPSPs in a higher proportion of BNST-AL cells $(\sim 80 \%)$ (Li et al., 2012) than BNST inputs to CeM neurons ( $\sim 60 \%$ ) (Gungor et al., 2015). Furthermore, the GABA-A reversal potential is more negative in BNST than CeA neurons by $\sim 10$ $\mathrm{mV}$ (Gungor et al., 2015). Together, these differences should conspire to give CeA the upper hand in reciprocal BNST-CeA interactions.

Complicating matters further, however, is the possibility that the impact of BNST inputs to CeM is altered via their actions in CeL. Indeed, different subsets of CeL neurons reciprocally inhibit each other and form different connections with CeM (Ciocchi et al., 2010; Haubensak et al., 2010; Viviani et al., 2011; Li et al., 2013). In particular, CeL cells that do not express somatostatin $\left(\mathrm{SOM}^{-}\right)$send GABAergic projections to $\mathrm{CeM}$, whereas $\mathrm{SOM}^{+}$neurons do not (Li et al., 2013). Thus, depending on whether BNST axons contact $\mathrm{SOM}^{+}$or SOM${ }^{-}$ CeL cells, the impact of BNST inputs in CeM might be dampened or increased, respectively. Given that these two types of CeL cells are thought to show opposite responses to threatening CSs in Pavlovian fear conditioning paradigms (Ciocchi et al., 2010; Haubensak et al., 2010), identifying which one receives inputs from, and projects to, BNST will be key to understand CeA-BNST interactions.

In conclusion, overall, the data reviewed here suggest that BNST's role is not limited to the generation of aversive responses to diffuse threats but that it also shapes the impact of discrete threatening stimuli. In threatening conditions, antagonistic interactions between BNST and CeA likely determine the intensity and specificity of aversive responses. However, BNST-AL and CeL cells express a variety of peptides that might affect how these two regions interact. In addition, much evidence indicates that BNST's influence over anxiety depends on several functionally distinct cell groups and BNST regions. Within BNST-AL, CRF-expressing cells in the oval nucleus are recruited by threats and stressors, but it remains unclear how they alter the activity of neurons in the rest of BNST and in its targets. Non-CRF BNST-AL cells might exert an anxiolytic influence, but their interaction with CRF cells remains largely uncharacterized. Similarly, GABAergic and glutamatergic BNST-AV neurons regu- 
late their targets (e.g., PVN, VTA) in opposite ways, but we know little about how they influence each other. Last, recent data suggest that BNST-AM is also involved in generating defensive behaviors. To shed light on how BNST contributes to anxiety, we need to characterize the interplay between these different BNST subregion and the various cell types therein.

Response from Dual Perspective Companion AuthorsAlexander J. Shackman and Andrew S. Fox

Anxiety disorders impose a staggering burden on public health, existing treatments are inconsistently effective, and the development of new therapeutics has stalled (Hyman, 2014). The central extended amygdala, including the central nucleus of the amygdala (Ce) and bed nucleus of the stria terminalis (BST), plays a pivotal role in contemporary models of fear and anxiety (Fox et al., 2015; Tovote et al., 2015). Yet, key aspects of its functional architecture have only recently come into focus. Gungor and Paré provide an insightful review of recent progress, focusing on work in rodents.

Gungor and Paré make it clear that both the Ce and BST are involved in modulating phasic and sustained responses to threat. For example, Gungor and Paré show that a sizable number of BST neurons rapidly respond to punctate threat and safety cues. This contradicts the hypothesis that the BST is a "sluggish" system and only responds to persistent threat (Davis, 2006). Building on this observation, they highlight evidence showing that the BST plays a crucial role in shaping phasic responses to acute cues when they are encountered in potentially dangerous contexts and contributes to the "overgeneralization" of fear and anxiety (Kheirbek et al., 2012; Lissek, 2012). As noted in our companion review, other work suggests that the lateral Ce also contributes to overgeneralization. These observations are particularly important because, in humans, overgeneralization marks populations at risk for developing anxiety disorders (e.g., Barker et al., 2014; Gazendam et al., 2015), promotes maladaptive avoidance (Grillon, 2002), predicts the future emergence of anxiety disorders (e.g., Craske et al., 2012), and distinguishes anxiety patients from controls (Duits et al., 2015).

Gungor and Paré emphasize that the BST can be partitioned into subregions, each containing intermingled cell types with distinct, even opposing, functional phenotypes. This indicates that inferences drawn from excitotoxic lesion, pharmacological inactivation, or neuroimaging studies will necessarily reflect a mixture of cellular signals. At present, the tools required to parse these signals do not exist for use in humans. Conversely, there is no guarantee that the mechanisms identified in animal models are evolutionarily conserved and will translate to humans. Understanding the relevance of these intermixed signals to the subjective feelings that define neuropsychiatric disease will therefore require coordinated cross-species research and the development of bidirectional translational models combining precise mechanistic techniques with whole-brain imaging. Inconsistent nomenclature is another important barrier.
For example, in our companion review, we argue that researchers should refrain from using the words "fear" and "anxiety" to refer to phasic and sustained responses to threat because it is inconsistent with everyday usage of these terms.

As outlined in the two Dual Perspective reviews, there is compelling evidence that the central extended amygdala plays a key role in orchestrating phasic and sustained responses to threat. The development and refinement of integrated bidirectional models would open the door to identifying the specific molecules, cells, and circuits that mediate effects detected in human imaging studies (compare Ferenczi et al., 2016) and accelerate the of development of improved treatments for pathological fear and anxiety.

\section{References}

Barker TV, Reeb-Sutherland BC, Fox NA (2014) Individual differences in fear potentiated startle in behaviorally inhibited children. Dev Psychobiol 56:133-141. CrossRef Medline

Craske MG, Wolitzky-Taylor KB, Mineka S, Zinbarg R, Waters AM, Vrshek-Schallhorn S, Epstein A, Naliboff B, Ornitz E (2012) Elevated responding to safe conditions as a specific risk factor for anxiety versus depressive disorders: evidence from a longitudinal investigation. J Abnorm Psychol 121:315-324. CrossRef Medline Davis M (2006) Neural systems involved in fear and anxiety measured with fear-potentiated startle. Am Psychol 61:741756. CrossRef Medline

Duits P, Cath DC, Lissek S, Hox JJ, Hamm AO, Engelhard IM, van den Hout MA, Baas JM (2015) Updated meta-analysis of classical fear conditioning in the anxiety disorders. Depress Anxiety 32:239253. CrossRef Medline

Ferenczi EA, Zalocusky KA, Liston C, Grosenick L, Warden MR, Amatya D, Katovich K, Mehta H, Patenaude B, Ramakrishnan C, Kalanithi P, Etkin A, Knutson B, Glover GH, Deisseroth K (2016) Prefrontal cortical regulation of brainwide circuit dynamics and reward-related behavior. Science 351:aac9698. CrossRef Medline Fox AS, Oler JA, Tromp do PM, Fudge JL, Kalin NH (2015) Extending the amygdala in theories of threat processing. Trends Neurosci 38:319-329. CrossRef Medline

Gazendam FJ, Kamphuis JH, Eigenhuis A, Huizenga HMH, Soeter M, Bos MGN, Sevenster D, Kindt M (2015) Personality predicts individual variation in fear learning: a multilevel growth modeling approach. Clin Psychol Sci 3:175-188. CrossRef Grillon C (2002) Associative learning deficits increase symptoms of anxiety in humans. Biol Psychiatry 51:851-858. CrossRef Medline

Hyman SE (2014) Revitalizing psychiatric therapeutics. Neuropsychopharmacology 39:220-229. CrossRef Medline

Kheirbek MA, Klemenhagen KC, Sahay A, Hen R (2012) Neurogenesis and generalization: a new approach to stratify and treat anxiety disorders. Nat Neurosci 15:1613-1620. CrossRef Medline Lissek S (2012) Toward an account of clinical anxiety predicated on basic, neurally mapped mechanisms of Pavlovian fear-learning: the case for conditioned overgeneralization. Depress Anxiety 29:257-263. CrossRef Medline

Tovote P, Fadok JP, Lüthi A (2015) Neuronal circuits for fear and anxiety. Nat Rev Neurosci 16:317-331. CrossRef Medline

\section{References}

Adhikari A, Lerner TN, Finkelstein J, Pak S, Jennings JH, Davidson TJ, Davidson TJ, Ferenczi E, Gunaydin LA, Mirzabekov JJ, Ye L, Kim SY, Lei A, Deisseroth K (2015) Basomedial amygdala mediates top-down control of anxiety and fear. Nature 527:179-185. CrossRef Medline

Aston-Jones G, Harris GC (2004) Brain substrates for increased drug seeking during protracted withdrawal. Neuropharmacology 47:167-179. CrossRef Medline 
Avery SN, Clauss JA, Blackford JU (2016) The human BNST: functional role in anxiety and addiction. Neuropsychopharmacology 41:126-141. CrossRef Medline

Bienkowski MS, Rinaman L (2013) Common and distinct neural inputs to the medial central nucleus of the amygdala and anterior ventrolateral bed nucleus of stria terminalis in rats. Brain Struct Funct 218:187-208. CrossRef Medline

Breitfeld T, Bruning JE, Inagaki H, Takeuchi Y, Kiyokawa Y, Fendt M (2015) Temporary inactivation of the anterior part of the bed nucleus of the stria terminalis blocks alarm pheromone induced defensive behavior in rats. Front Neurosci 9:321. CrossRef Medline

Buffalari DM, See RE (2010) Inactivation of the bed nucleus of the stria terminalis in an animal model of relapse: effects on conditioned cueinduced reinstatement and its enhancement by yohimbine. Psychopharmacology (Berl) 213:19-27. CrossRef Medline

Choi DC, Furay AR, Evanson NK, Ostrander MM, Ulrich-Lai YM, Herman JP (2007) Bed nucleus of the stria terminalis subregions differentially regulates hypothalamic-pituitary-adrenal axis activity: implications for the integration of limbic inputs. J Neurosci 27:2025-2034. CrossRef Medline

Ciocchi S, Herry C, Grenier F, Wolff SB, Letzkus JJ, Vlachos I, Ehrlich I, Sprengel R, Deisseroth K, Stadler MB, Müller C, Lüthi A (2010) Encoding of conditioned fear in central amygdala inhibitory circuits. Nature 468:277-282. CrossRef Medline

Conrad KL, Louderback KM, Gessner CP, Winder DG (2011) Stressinduced alterations in anxiety-like behavior and adaptations in plasticity in the bed nucleus of the stria terminalis. Physiol Behav 104:248-256. CrossRef Medline

Conrad LC, Pfaff DW (1976a) Efferents from medial basal forebrain and hypothalamus in the rat: II. An autoradiographic study of the anterior hypothalamus. J Comp Neurol 169:221-261. CrossRef Medline

Conrad LC, Pfaff DW (1976b) Efferents from medial basal forebrain and hypothalamus in the rat: I. An autoradiographic study of the medial preoptic area. J Comp Neurol 169:185-219. CrossRef Medline

Crane JW, Buller KM, Day TA (2003) Evidence that the bed nucleus of the stria terminalis contributes to the modulation of hypophysiotropic corticotropin-releasing factor cell responses to systemic interleukin- $1 \beta$. J Comp Neurol 467:232-242. CrossRef Medline

Csáki A, Kocsis K, Halász B, Kiss J (2000) Localization of glutamatergic/ aspartatergic neurons projecting to the hypothalamic paraventricular nucleus studied by retrograde transport of [H-3]D-aspartate autoradiography. Neuroscience 101:637-655. CrossRef Medline

Cullinan WE, Herman JP, Watson SJ (1993) Ventral subicular interaction with the hypothalamic paraventricular nucleus: evidence for a relay in the bed nucleus of the stria terminalis. J Comp Neurol 332:1-20. CrossRef Medline

Dabrowska J, Hazra R, Guo JD, Dewitt S, Rainnie DG (2013a) Central CRF neurons are not created equal: phenotypic differences in CRF-containing neurons of the rat paraventricular hypothalamus and the bed nucleus of the stria terminalis. Front Neurosci 7:156. CrossRef Medline

Dabrowska J, Hazra R, Guo JD, Li C, Dewitt S, Xu J, Lombroso PJ, Rainnie DG (2013b) Striatal-enriched protein tyrosine phosphatase-STEPs towards understanding chronic stress induced activation of corticotrophin releasing factor neurons in the rat bed nucleus of the stria terminalis. Biol Psychiatry 74:817-826. CrossRef Medline

Daniel SE, Rainnie DG (2016) Stress modulation of opposing circuits in the bed nucleus of the stria terminalis. Neuropsychopharmacology 41:103125. CrossRef Medline

Dong HW, Swanson LW (2003) Projections from the rhomboid nucleus of the bed nuclei of the stria terminalis: implications for cerebral hemisphere regulation of ingestive behaviors. J Comp Neurol 463:434-472. CrossRef Medline

Dong HW, Swanson LW (2004) Organization of axonal projections from the anterolateral area of the bed nuclei of the stria terminalis. J Comp Neurol 468:277-298. CrossRef Medline

Dong HW, Swanson LW (2006a) Projections from bed nuclei of the stria terminalis, anteromedial area: cerebral hemisphere integration of neuroendocrine, autonomic, and behavioral aspects of energy balance. J Comp Neurol 494:142-178. CrossRef Medline

Dong HW, Swanson LW (2006b) Projections from bed nuclei of the stria terminalis, magnocellular nucleus: implications for cerebral hemisphere regulation of micturition, defecation, and penile erection. J Comp Neurol 494:108-141. CrossRef Medline
Dong HW, Swanson LW (2006c) Projections from bed nuclei of the stria terminalis, dorsomedial nucleus: implications for cerebral hemisphere integration of neuroendocrine, autonomic, and drinking responses. J Comp Neurol 494:75-107. CrossRef Medline

Dong H, Petrovich GD, Swanson LW (2000) Organization of projections from the juxtacapsular nucleus of the BST: a PHAL study in the rat. Brain Res 859:1-14. CrossRef Medline

Dong HW, Petrovich GD, Swanson LW (2001a) Topography of projections from amygdala to bed nuclei of the stria terminalis. Brain Res Rev 38:192246. CrossRef Medline

Dong HW, Petrovich GD, Watts AG, Swanson LW (2001b) Basic organization of projections from the oval and fusiform nuclei of the bed nuclei of the stria terminalis in adult rat brain. J Comp Neurol 436:430-455. CrossRef Medline

Dunn JD (1987) Plasma corticosterone responses to electrical stimulation of the bed nucleus of the stria terminalis. Brain Res 407:327-331. CrossRef Medline

Duvarci S, Bauer EP, Paré D (2009) The bed nucleus of the stria terminalis mediates inter-individual variations in anxiety and fear. J Neurosci 29 : 10357-10361. CrossRef Medline

Erb S, Stewart J (1999) A role for the bed nucleus of the stria terminalis, but not the amygdala, in the effects of corticotropin-releasing factor on stressinduced reinstatement of cocaine seeking. J Neurosci 19:RC35. Medline

Fallon JH, Moore RY (1978) Catecholamine innervation of the basal forebrain. J Comp Neurol 180:545-580. CrossRef Medline

Fanselow MS, Kim JJ (1994) Acquisition of contextual Pavlovian fear conditioning is blocked by application of an NMDA receptor antagonist D, L-2-amino-5-phosphonovaleric acid to the basolateral amygdala. Behav Neurosci 108:210-212. CrossRef Medline

Fendt M, Endres T, Apfelbach R (2003) Temporary inactivation of the bed nucleus of the stria terminalis but not of the amygdala blocks freezing induced by trimethylthiazoline, a component of fox feces. J Neurosci 23:23-28. Medline

Forray MI, Gysling K, Andrés ME, Bustos G, Araneda S (2000) Medullary noradrenergic neurons projecting to the bed nucleus of the stria terminalis express mRNA for the NMDA-NR1 receptor. Brain Res Bull 52:163169. CrossRef Medline

Francesconi W, Berton F, Koob GF, Sanna PP (2009) Intrinsic neuronal plasticity in the juxtacapsular nucleus of the bed nuclei of the stria terminalis (jcBNST). Prog Neuropsychopharmacol Biol Psychiatry 33:13471355. CrossRef Medline

Fu LY, van den Pol AN (2008) Agouti-related peptide and MC3/4 receptor agonists both inhibit excitatory hypothalamic ventromedial nucleus neurons. J Neurosci 28:5433-5449. CrossRef Medline

Georges F, Aston-Jones G (2002) Activation of ventral tegmental area cells by the bed nucleus of the stria terminalis: a novel excitatory amino acid input to midbrain dopamine neurons. J Neurosci 22:5173-5187. Medline

Gewirtz JC, McNish KA, Davis M (1998) Lesions of the bed nucleus of the stria terminalis block sensitization of the acoustic startle reflex produced by repeated stress but not fear potentiated startle. Prog Neuropsychopharmacol Biol Psychiatry 22:625-648. CrossRef Medline

Goosens KA, Maren S (2001) Contextual and auditory fear conditioning are mediated by the lateral, basal, and central amygdaloid nuclei in rats. Learn Mem 8:148-155. CrossRef Medline

Goosens KA, Maren S (2003) Pretraining NMDA receptor blockade in the basolateral complex, but not the central nucleus, of the amygdala prevents savings of conditional fear. Behav Neurosci 117:738-750. CrossRef Medline

Gray TS, Magnuson DJ (1987) Neuropeptide neuronal efferents from the bed nucleus of the stria terminalis and central amygdaloid nucleus to the dorsal vagal complex in the rat. J Comp Neurol 262:365-374. CrossRef Medline

Gray TS, Magnuson DJ (1992) Peptide immunoreactive neurons in the amygdala and the bed nucleus of the stria terminalis project to the midbrain central gray in the rat. Peptides 13:451-460. CrossRef Medline

Gross CT, Canteras NS (2012) The many paths to fear. Nat Rev Neurosci 13:651-658. CrossRef Medline

Grupe DW, Nitschke JB (2013) Uncertainty and anticipation in anxiety: an integrated neurobiological and psychological perspective. Nat Rev Neurosci 14:488-501. CrossRef Medline

Gungor NZ, Paré D (2014) CGRP inhibits neurons of the bed nucleus of the 
stria terminalis: implications for the regulation of fear and anxiety. J Neurosci 34:60-65. CrossRef Medline

Gungor NZ, Yamamoto R, Paré D (2015) Optogenetic study of the projections from the bed nucleus of the stria terminalis to the central amygdala. J Neurophysiol 114:2903-2911. CrossRef Medline

Hammack SE, Mania I, Rainnie DG (2007) Differential expression of intrinsic membrane currents in defined cell types of the anterolateral bed nucleus of the stria terminalis. J Neurophysiol 98:638-656. CrossRef Medline

Hammack SE, Todd TP, Kocho-Schellenberg M, Bouton ME (2015) Role of the bed nucleus of the stria terminalis in the acquisition of contextual fear at long or short context shock intervals. Behav Neurosci 129:673-678. CrossRef Medline

Haubensak W, Kunwar PS, Cai H, Ciocchi S, Wall NR, Ponnusamy R, Biag J, Dong HW, Deisseroth K, Callaway EM, Fanselow MS, Lüthi A, Anderson DJ (2010) Genetic dissection of an amygdala microcircuit that gates conditioned fear. Nature 468:270-276. CrossRef Medline

Haufler D, Nagy FZ, Paré D (2013) Neuronal correlates of fear conditioning in the bed nucleus of the stria terminalis. Learn Mem 20:633-641. CrossRef Medline

Hazra R, Guo JD, Ryan SJ, Jasnow AM, Dabrowska J, Rainnie DG (2011) A transcriptomic analysis of type I-III neurons in the bed nucleus of the stria terminalis. Mol Cell Neurosci 46:699-709. CrossRef Medline

Henke PG (1984) The bed nucleus of the stria terminalis and immobilization-stress. Behav Brain Res 11:35-45. CrossRef Medline

Herman JP, Ostrander MM, Mueller NK, Figueiredo H (2005) Limbic system mechanisms of stress regulation: hypothalamo-pituitaryadrenocortical axis. Prog Neuropsychopharmacol Biol Psychiatry 29: 1201-1213. CrossRef Medline

Hitchcock JM, Davis M (1991) Efferent pathway of the amygdala involved in conditioned fear as measured with the fear-potentiated startle paradigm. Behav Neurosci 105:826-842. CrossRef Medline

Ide S, Hara T, Ohno A, Tamano R, Koseki K, Naka T, Maruyama C, Kaneda K, Yoshioka M, Minami M (2013) Opposing roles of corticotrophin releasing factor and neuropeptide $\mathrm{Y}$ within the dorsolateral bed nucleus of the stria terminalis in the negative component of pain in rats. J Neurosci 33:5881-5894. CrossRef Medline

Jaferi A, Pickel VM (2009) Mu-opioid and corticotrophin releasing factor receptors show largely postsynaptic co-expression and separate presynaptic distributions in the mouse central amygdala and bed nucleus of the stria terminalis. Neuroscience 159:526-539. CrossRef Medline

Jaferi A, Lane DA, Pickel VM (2009) Subcellular plasticity of the corticotrophin releasing factor receptor in dendrites of the mouse bed nucleus of the stria terminalis following chronic opiate exposure. Neuroscience 163: 143-154. CrossRef Medline

Jennings JH, Sparta DR, Stamatakis AM, Ung RL, Pleil KE, Kash TL, Stuber GD (2013) Distinct extended amygdala circuits for divergent motivational states. Nature 496:224-228. CrossRef Medline

Ju G, Swanson LW (1989) Studies on the cellular architecture of the bed nuclei of the stria terminalis in the rat: I. Cytoarchitecture. J Comp Neurol 280:587-602. CrossRef Medline

Ju G, Swanson LW, Simerly RB (1989) Studies on the cellular architecture of the bed nuclei of the stria terminalis in the rat: II. Chemoarchitecture. J Comp Neurol 280:603-621. CrossRef Medline

Justice NJ, Yuan ZF, Sawchenko PE, Vale W (2008) Type 1 corticotropin releasing factor receptor expression reported in BAC transgenic mice: implications for reconciling ligand-receptor mismatch in the central corticotropin releasing factor system. J Comp Neurol 511:479-496. CrossRef Medline

Kash TL, Winder DG (2006) Neuropeptide Y and corticotrophin releasing factor bi-directionally modulate inhibitory synaptic transmission in the bed nucleus of the stria terminalis. Neuropharmacology 51:1013-1022. CrossRef Medline

Kash TL, Nobis WP, Matthews RT, Winder DG (2008) Dopamine enhances fast excitatory synaptic transmission in the extended amygdala by a CRFR1-dependent process. J Neurosci 28:13856-13865. CrossRef Medline

Kim SY, Adhikari A, Lee SY, Marshel JH, Kim CK, Mallory CS, Lo M, Pak S, Mattis J, Lim BK, Malenka RC, Warden MR, Neve R, Tye KM, Deisseroth K (2013) Diverging neural pathways assemble a behavioral state from separable features in anxiety. Nature 496:219-223. CrossRef Medline

Kita H, Oomura Y (1982a) An HRP study of the afferent connections to rat lateral hypothalamic region. Brain Res Bull 8:63-71. CrossRef Medline
Kita H, Oomura Y (1982b) An HRP study of the afferent connections to rat medial hypothalamic region. Brain Res Bull 8:53-62. CrossRef Medline

Koob GF (2009) Brain stress systems in the amygdala and addiction. Brain Res 1293:61-75. CrossRef Medline

Koob GF (2010) The role of CRF and CRF-related peptides in the dark side of addiction. Brain Res 1314:3-14. CrossRef Medline

Krettek JE, Price JL (1978a) Amygdaloid projections to subcortical structures within the basal forebrain and brainstem in the rat and cat. J Comp Neurol 178:225-254. CrossRef Medline

Krettek JE, Price JL (1978b) A description of the amygdaloid complex in the rat and cat with observations on intra-amygdaloid axonal connections. J Comp Neurol 178:255-280. CrossRef Medline

Kudo T, Uchigashima M, Miyazaki T, Konno K, Yamasaki M, Yanagawa Y, Minami M, Watanabe M (2012) Three types of neurochemical projection from the bed nucleus of the stria terminalis to the ventral tegmental area in adult mice. J Neurosci 32:18035-18046. CrossRef Medline

Larriva-Sahd J (2006) Histological and cytological study of the bed nuclei of the stria terminalis in adult rat: II. Oval nucleus: extrinsic inputs, cell types, neuropil, and neuronal modules. J Comp Neurol 497:772-807. CrossRef Medline

LeDoux JE, Iwata J, Cicchetti P, Reis DJ (1988) Different projections of the central amygdaloid nucleus mediate autonomic and behavioral correlates of conditioned fear. J Neurosci 8:2517-2529. Medline

Lee H, Kim DW, Remedios R, Anthony TE, Chang A, Madisen L, Zeng H, Anderson DJ (2014) Scalable control of mounting and attack by Esr ${ }^{+}$ neurons in the ventromedial hypothalamus. Nature 509:627-632. CrossRef Medline

Lee Y, Davis M (1997) Role of hippocampus, the bed nucleus of the stria terminalis, and the amygdala in the excitatory effect of corticotropin releasing hormone on the acoustic startle reflex. J Neurosci 17:6434-6446. Medline

Li CI, Maglinao TL, Takahashi LK (2004) Medial amygdala modulation of predator odor induced unconditioned fear in the rat. Behav Neurosci 118:324-332. CrossRef Medline

Li C, Pleil KE, Stamatakis AM, Busan S, Vong L, Lowell BB, Stuber GD, Kash TL (2012) Presynaptic inhibition of gamma-aminobutyric acid release in the bed nucleus of the stria terminalis by kappa opioid receptor signaling. Biol Psychiatry 71:725-732. CrossRef Medline

Li C, Sugam JA, Lowery-Gionta EG, McElligott ZA, McCall NM, Lopez AJ, McKlveen JM, Pleil KE, Kash TL (2016) Mu opioid receptor modulation of dopamine neurons in the periaqueductal gray/dorsal raphe: a role in regulation of pain. Neuropsychopharmacology 41:2122-2132. CrossRef Medline

Li H, Penzo MA, Taniguchi H, Kopec CD, Huang ZJ, Li B (2013) Experience-dependent modification of a central amygdala fear circuit. Nat Neurosci 16:332-339. CrossRef Medline

Li S, Kirouac GJ (2008) Projections from the paraventricular nucleus of the thalamus to the forebrain with special emphasis on the extended amygdala. J Comp Neurol 506:263-287. CrossRef Medline

McDonald AJ (1983) Neurons of the bed nucleus of the stria terminalis: a Golgi study in the rat. Brain Res Bull 10:111-120. CrossRef Medline

McDonald AJ, Shammah-Lagnado SJ, Shi C, Davis M (1999) Cortical afferents to the extended amygdala. Ann N Y Acad Sci 877:309-338. CrossRef Medline

McElligott ZA, Klug JR, Nobis WP, Patel S, Grueter BA, Kash TL, Winder DG (2010) Distinct forms of Gq-receptor-dependent plasticity of excitatory transmission in the BNST are differentially affected by stress. Proc Natl Acad Sci U S A 107:2271-2276. CrossRef Medline

Meloni EG, Jackson A, Gerety LP, Cohen BM, Carlezon WA (2006) Role of the bed nucleus of the stria terminalis (BST) in the expression of conditioned fear. Ann N Y Acad Sci 1071:538-541. CrossRef Medline

Moga MM, Saper CB (1994) Neuropeptide-immunoreactive neurons projecting to the paraventricular hypothalamic nucleus in the rat. J Comp Neurol 346:137-150. CrossRef Medline

Moga MM, Saper CB, Gray TS (1989) Bed nucleus of the stria terminalis: cytoarchitecture, immunohistochemistry, and projection to the parabrachial nucleus in the rat. J Comp Neurol 283:315-332. CrossRef Medline

Möller C, Wiklund L, Sommer W, Thorsell A, Heilig M (1997) Decreased experimental anxiety and voluntary ethanol consumption in rats following central but not basolateral amygdala lesions. Brain Res 760:94-101. CrossRef Medline

Moreira CM, Masson S, Carvalho MC, Brandão ML (2007) Exploratory 
behavior of rats in the elevated plus maze is differentially sensitive to inactivation of the basolateral and central amygdaloid nuclei. Brain Res Bull 71:466-474. CrossRef Medline

Nagano Y, Kaneda K, Maruyama C, Ide S, Kato F, Minami M (2015) Corticotropin releasing factor enhances inhibitory synaptic transmission to type III neurons in the bed nucleus of the stria terminalis. Neurosci Lett 600:56-61. CrossRef Medline

Nobis WP, Kash TL, Silberman Y, Winder DG (2011) Beta adrenergic receptors enhance excitatory transmission in the bed nucleus of the stria terminalis through a corticotrophin releasing factor dependent and cocaine regulated mechanism. Biol Psychiatry 69:1083-1090. CrossRef Medline

Norgren R (1976) Taste pathways to hypothalamus and amygdala. J Comp Neurol 166:17-30. CrossRef Medline

Panguluri S, Saggu S, Lundy R (2009) Comparison of somatostatin and corticotropin-releasing hormone immunoreactivity in forebrain neurons projecting to taste-responsive and non-responsive regions of the parabrachial nucleus in rat. Brain Res 1298:57-69. CrossRef Medline

Petrovich GD, Risold PY, Swanson LW (1996) Organization of projections from the basomedial nucleus of the amygdala: a PHAL study in the rat. J Comp Neurol 374:387-420. CrossRef Medline

Phelix CF, Paull WK (1990) Demonstration of distinct corticotropin releasing factor-containing neuron populations in the bed nucleus of the stria terminalis: a light and electron microscopic immunocytochemical study in the rat. Histochemistry 94:345-364. Medline

Pitts MW, Todorovic C, Blank T, Takahashi LK (2009) The central nucleus of the amygdala and corticotrophin releasing factor: insights into contextual fear memory. J Neurosci 29:7379-7388. CrossRef Medline

Pleil KE, Rinker JA, Lowery-Gionta EG, Mazzone CM, McCall NM, Kendra AM, Olson DP, Lowell BB, Grant KA, Thiele TE, Kash TL (2015) NPY signaling inhibits extended amygdala CRF neurons to suppress binge alcohol drinking. Nat Neurosci 18:545-552. CrossRef Medline

Polston EK, Gu G, Simerly RB (2004) Neurons in the principal nucleus of the bed nuclei of the stria terminalis provide a sexually dimorphic GABAergic input to the anteroventral periventricular nucleus of the hypothalamus. Neuroscience 123:793-803. CrossRef Medline

Potter E, Sutton S, Donaldson C, Chen R, Perrin M, Lewis K, Sawchenko PE, Vale W (1994) Distribution of corticotropin releasing factor receptor mRNA expression in the rat brain and pituitary. Proc Natl Acad Sci U S A 91:8777-8781. CrossRef Medline

Poulin JF, Arbour D, Laforest S, Drolet G (2009) Neuroanatomical characterization of endogenous opioids in the bed nucleus of the stria terminalis. Prog Neuropsychopharmacol Biol Psychiatry 33:1356-1365. CrossRef Medline

Poulos AM, Ponnusamy R, Dong HW, Fanselow MS (2010) Compensation in the neural circuitry of fear conditioning awakens learning circuits in the bed nuclei of the stria terminalis. Proc Natl Acad Sci U S A 107:1488114886. CrossRef Medline

Prewitt CM, Herman JP (1998) Anatomical interactions between the central amygdaloid nucleus and the hypothalamic paraventricular nucleus of the rat: a dual tract-tracing analysis. J Chem Neuroanat 15:173-185. CrossRef Medline

Radley JJ, Sawchenko PE (2011) A common substrate for prefrontal and hippocampal inhibition of the neuroendocrine stress response. J Neurosci 31:9683-9695. CrossRef Medline

Radley JJ, Gosselink KL, Sawchenko PE (2009) A discrete GABAergic relay mediates medial prefrontal cortical inhibition of the neuroendocrine stress response. J Neurosci 29:7330-7340. CrossRef Medline

Reynolds SM, Zahm DS (2005) Specificity in the projections of prefrontal and insular cortex to ventral striatopallidum and the extended amygdala. J Neurosci 25:11757-11767. CrossRef Medline

Ricardo JA, Koh ET (1978) Anatomical evidence of direct projections from the nucleus of the solitary tract to the hypothalamus, amygdala, and other forebrain structures. Brain Res 153:1-26. CrossRef Medline

Rodriguez-Sierra OE, Turesson HK, Paré D (2013) Contrasting distribution of physiological cell types in different regions of the bed nucleus of the stria terminalis. J Neurophysiol 110:2017-2049. CrossRef Medline

Rosen JB (2004) The neurobiology of conditioned and unconditioned fear: a neurobehavioral system analysis of amygdala. Behav Cogn Neurosci Rev 3:23-41. CrossRef Medline

Sahuque LL, Kullberg EF, McGeehan AJ, Kinder JR, Hicks MP, Blanton MG, Janak PH, Olive MF (2006) Anxiogenic and aversive effects of cortico- trophin releasing factor in the bed nucleus of the stria terminalis in the rat: role of CRF receptor subtypes. Psychopharmacology (Berl) 186:122-132. CrossRef Medline

Sakanaka M, Shibasaki T, Lederis K (1986) Distribution and efferent projections of corticotropin-releasing factor-like immunoreactivity in the rat amygdaloid complex. Brain Res 382:213-238. CrossRef Medline

Sakanaka M, Shibasaki T, Lederis K (1987) Corticotropin releasing factorlike immunoreactivity in the rat brain as revealed by a modified cobaltglucose oxidase-diaminobenzidine method. J Comp Neurol 260:256298. CrossRef Medline

Saper CB, Loewy AD (1980) Efferent connections of the parabrachial nucleus in the rat. Brain Res 197:291-317. CrossRef Medline

Saper CB, Swanson LW, Cowan WM (1976) The efferent connections of the ventromedial nucleus of the hypothalamus of the rat. J Comp Neurol 169:409-442. CrossRef Medline

Sawchenko PE, Swanson LW (1983) The organization of forebrain afferents to the paraventricular and supraoptic nuclei of the rat. J Comp Neurol 218:121-144. CrossRef Medline

Schwaber JS, Kapp BS, Higgins GA, Rapp PR (1982) Amygdaloid and basal forebrain direct connections with the nucleus of the solitary tract and the dorsal motor nucleus. J Neurosci 2:1424-1438. Medline

Shackman AJ, Fox AS (2016) Contributions of the central extended amygdala to fear and anxiety. J Neurosci 36:8050-8063. CrossRef

Shin JW, Geerling JC, Loewy AD (2008) Inputs to the ventrolateral bed nucleus of the stria terminalis. J Comp Neurol 511:628-657. CrossRef Medline

Silberman Y, Matthews RT, Winder DG (2013) A corticotrophin releasing factor pathway for ethanol regulation of the ventral tegmental area in the bed nucleus of the stria terminalis. J Neurosci 33:950-960. CrossRef Medline

Silva BA, Mattucci C, Krzywkowski P, Murana E, Illarionova A, Grinevich V, Canteras NS, Ragozzino D, Gross CT (2013) Independent hypothalamic circuits for social and predator fear. Nat Neurosci 16:1731-1733. CrossRef Medline

Simerly RB (2002) Wired for reproduction: organization and development of sexually dimorphic circuits in the mammalian forebrain. Annu Rev Neurosci 25:507-536. CrossRef Medline

Sink KS, Walker DL, Yang Y, Davis M (2011) Calcitonin gene related peptide in the bed nucleus of the stria terminalis produces an anxiety like pattern of behavior and increases neural activation in anxiety related structures. J Neurosci 31:1802-1810. CrossRef Medline

Sofroniew MV (1983) Direct reciprocal connections between the bed nucleus of the stria terminalis and dorsomedial medulla oblongata: evidence from immunohistochemical detection of tracer proteins. J Comp Neurol 213:399-405. CrossRef Medline

Spencer SJ, Buller KM, Day TA (2005) Medial prefrontal cortex control of the paraventricular hypothalamic nucleus response to psychological stress: possible role of the bed nucleus of the stria terminalis. J Comp Neurol 481:363-376. CrossRef Medline

Sullivan GM, Apergis J, Bush DE, Johnson LR, Hou M, Ledoux JE (2004) Lesions in the bed nucleus of the stria terminalis disrupt corticosterone and freezing responses elicited by a contextual but not by a specific cueconditioned fear stimulus. Neuroscience 128:7-14. CrossRef Medline

Sun N, Cassell MD (1993) Intrinsic GABAergic neurons in the rat central amygdala. J Comp Neurol 330:381-404. CrossRef Medline

Sun N, Roberts L, Cassell MD (1991) Rat central amygdaloid nucleus projections to the bed nucleus of the stria terminalis. Brain Res Bull 27:651662. CrossRef Medline

Swanson LW (1976) An autoradiographic study of the efferent connections of the preoptic region in the rat. J Comp Neurol 167:227-256. CrossRef Medline

Swanson LW, Cowan WM (1979) The connections of the septal region in the rat. J Comp Neurol 186:621-655. CrossRef Medline

Szücs A, Berton F, Nowotny T, Sanna P, Francesconi W (2010) Consistency and diversity of spike dynamics in the neurons of bed nucleus of stria terminalis of the rat: a dynamic clamp study. PLoS One 5:e11920. CrossRef Medline

Turesson HK, Rodriguez-Sierra OE, Paré D (2013) Intrinsic connections in the anterior part of the bed nucleus of the stria terminalis. J Neurophysiol 109:2438-2450. CrossRef Medline

Van Pett K, Viau V, Bittencourt JC, Chan RK, Li HY, Arias C, Prins GS, Perrin M, Vale W, Sawchenko PE (2000) Distribution of mRNAs encoding CRF re- 
ceptors in brain and pituitary of rat and mouse. J Comp Neurol 428:191-212. CrossRef Medline

Viviani D, Charlet A, van den Burg E, Robinet C, Hurni N, Abatis M, Magara F, Stoop R (2011) Oxytocin selectively gates fear responses through distinct outputs from the central amygdala. Science 333:104-107. CrossRef Medline

Waddell J, Morris RW, Bouton ME (2006) Effects of bed nucleus of the stria terminalis lesions on conditioned anxiety: aversive conditioning with long-duration conditional stimuli and reinstatement of extinguished fear. Behav Neurosci 120:324-336. CrossRef Medline

Walker DL, Davis M (1997) Double dissociation between the involvement of the bed nucleus of the stria terminalis and the central nucleus of the amygdala in startle increases produced by conditioned versus unconditioned fear. J Neurosci 17:9375-9383. Medline

Walker DL, Miles LA, Davis M (2009a) Selective participation of the bed nucleus of the stria terminalis and CRF in sustained anxiety-like versus phasic fear-like responses. Prog Neuropsychopharmacol Biol Psychiatry 33:1291-1308. CrossRef Medline

Walker D, Yang Y, Ratti E, Corsi M, Trist D, Davis M (2009b) Differential effects of the CRF-R1 antagonist GSK876008 on fear-potentiated, lightand CRF-enhanced startle suggest preferential involvement in sustained vs phasic threat responses. Neuropsychopharmacology 34:1533-1542. CrossRef Medline

Wang L, Goebel-Stengel M, Stengel A, Wu SV, Ohning G, Taché Y (2011) Comparison of CRF-immunoreactive neurons distribution in mouse and rat brains and selective induction of Fos in rat hypothalamic CRF neurons by abdominal surgery. Brain Res 1415:34-46. CrossRef Medline

Wang L, Chen IZ, Lin D (2015) Collateral pathways from the ventromedial hypothalamus mediate defensive behaviors. Neuron 85:1344-1358. CrossRef Medline

Weller KL, Smith DA (1982) Afferent connections to the bed nucleus of the stria terminalis. Brain Res 232:255-270. CrossRef Medline

Wenzel JM, Waldroup SA, Haber ZM, Su Z, Ben-Shahar O, Ettenberg A (2011) Effect of lidocaine induced inactivation of the bed nucleus of the stria terminalis, the central and the basolateral nucleus of the amygdala on the opponent process actions of self administered cocaine in rats. Psychopharmacology (Berl) 217:221-230. CrossRef Medline

Wenzel JM, Cotten SW, Dominguez HM, Lane JE, Shelton K, Su ZI, Ettenberg A (2014) Noradrenergic beta receptor antagonism within the central nucleus of the amygdala or bed nucleus of the stria terminalis attenuates the negative anxiogenic effects of cocaine. J Neurosci 34:34673474. CrossRef Medline

Woodhams PL, Roberts GW, Polak JM, Crow TJ (1983) Distribution of neuropeptides in the limbic system of the rat: the bed nucleus of the stria terminalis, septum and preoptic area. Neuroscience 8:677-703. CrossRef Medline

Xu HY, Liu YJ, Xu MY, Zhang YH, Zhang JX, Wu YJ (2012) Inactivation of the bed nucleus of the stria terminalis suppresses the innate fear responses of rats induced by the odor of cat urine. Neuroscience 221:21-27. CrossRef Medline 